\section{REFLEKSI HUKUM}

Jurnal Ilmu Hukum
p-ISSN 2541-4984 | e-ISSN 2541-5417

Volume 4 Nomor 2, April 2020, Halaman 195-216

DOI: https://doi.org/10.24246/jrh.2020.v4.i2.p195-216

Open access at: http://ejournal.uksw.edu/refleksihukum

Penerbit: Fakultas Hukum Universitas Kristen Satya Wacana

\title{
COMPETITION LAW HARMONIZATION: WHAT ASEAN CAN LEARN FROM OTHERS?
}

\author{
Cenuk Sayekti \\ Fakultas Hukum Universitas Lancang Kuning \\ Korespondensi: cenuk.sayekti@unilak.ac.id
}

Naskah dikirim: 8 Januari 2020|Direvisi: 25 Februari 2020|Disetujui: 27 April 2020

\begin{abstract}
Abstrak
Artikel ini bertujuan melakukan eksaminasi pada tantangan yang dijumpai oleh economic community dalam melakukan harmonisasi. Tujuan penulisan ini agar dapat menjadi pertimbangan bagi ASEAN dalam melakukan harmonisasi hukum persaingan usaha negaranegara anggotanya. Pada studi sebelumnya menyatakan bahwa kemungkinan dilakukannya harmonisasi hukum persaingan usaha di level regional adalah dengan menyesuaikan hukum pada negara-negara anggota dengan tujuan meminimalisir konflik hukum jika terjadi kasus lintas batas. Namun demikian, pada faktanya terdapat perbedaan yang sangat mendasar untuk dilakukan harmonisasi. Perbedaan-perbedaan tersebut menimbulkan permasalahan dalam praktik harmonisasi yang dialami oleh Uni Eropa maupun Amerika ketika terjadi kasus yang sifatnya lintas batas yurisdiksi nasional mereka, sehingga dapat mengambil hikmah dari kasus-kasus tersebut. Artikel ini difokuskan pada dua area pembahasan, yaitu: perbedaan dalam merespon market behaviour dan budaya hukum. Dari kedua hal tersebut ada beberapa pelajaran yang dapat diambil oleh ASEAN ketika melakukan harmonisasi persaingan usaha negara-negara anggotanya.
\end{abstract}

Kata-kata Kunci: HukumPersaingan Usaha; ASEAN; Harmonisasi.

\begin{abstract}
This article aims to examine the challenges encountered by the economic community while harmonizing their domestic laws. The purpose of this paper is to provide consideration for ASEAN to harmonize the competition laws among its member states. Some previous studies had confirmed that the possibility of harmonizing competition law at the regional level might happen if the member states could adjust their domestic laws. It could minimize the legal conflicts when cross-border cases occurred. However, there are fundamental differences to form the harmonization. Such differences had created practical problems in the European Union and the United States when the cross-border cases occurred. This article focuses on two areas of discussion, namely: differences of treatment to market behavior and differences in legal culture. From these areas, there are several lessons that ASEAN could take when harmonizing the competition law of its member countries.
\end{abstract}

Keywords: Competition Law; ASEAN; Harmonization. 


\section{INTRODUCTION}

ASEAN clearly stated its position as an economic community (AEC) in 2015 to create a single ASEAN market and production base, to make ASEAN more dynamic and competitive with other economic regions, to facilitate free movement of goods/services and free movement of skilled labor, also, to facilitate free movement of capital and investment. ${ }^{1}$

One of the imminent problems that the AEC must face is the current lack of a common competition provision. The AEC needs a policy that represents a prerequisite for free trade and for keeping the market free from restrictive business conduct. Common regulation is a requirement for establishing a regional single market. ${ }^{2}$ Since competition law is the central instrument of free trade, it has a major role in the process of liberalization within ASEAN to ensure the ASEAN market is accessible widely for new entrants and to prevent the internal market from anticompetitive conduct. ${ }^{3}$

ASEAN's commitment to help the economic integration through the AEC becomes the main reason to encourage the harmonization of competition law within ASEAN by endeavoring to introduce national competition law and policy by 2015. The claim that economic integration enhances the urgent call for harmonization of competition law relies on the argument that anti-competitive conduct across jurisdictions will increase. ${ }^{4}$ Another argument favoring the harmonization is different laws in the respective member states and a great number of other legal provisions impose different costs on the market. ${ }^{5}$ Legal diversity within the ASEAN will increase the transaction costs of cross-border economy transaction sand discourages firms from engaging in such transactions. 6

These conflicts are leading to a growing consciousness in the ASEAN economic community. Diversities in competition law among the member states within AEC will enhance crossborder economic transactions. ${ }^{7}$ Should the harmonization initiative be the answer to the legal uncertainty issue? What are the problems that ASEAN will be dealing with when they attempt to harmonize the national competition law of the members? These are

Siow Yue Chia, The ASEAN Economic Community: Progress, Challenges, and Prospects', A World Trade Organization for the 21st Century (Edward Elgar Publishing 2014) 14.

2 Candra Irawan, 'Legal Harmonization in ASEAN Economic Communities (Looking for the Best Legal Harmonization Model)' (2018) 3 (2) University Of Bengkulu Law Journal 134.

3 Lawan Thanadsillapakul, 'The Harmonization of ASEAN Laws and Policy and Economic Integration' (2004) 3 Uniform Law Review 479, 480.

4 Damien Neven and Paul Seabright, 'Trade Liberalization and the Coordination of Competition Policy' in William S Comanor, Akira Goto and Leonard Waverman (eds), Competition Policy in the Global Economy: Modalities for Co-operation (Routledge 2005) 334-355.

5 Caroline Cauffman and Niels J Philipsen, 'Who Does What in Competition Law: Harmonizing the Rules on Damages for Infringements of the EU Competition Rules?' Maastricht European Private Law Institute Working Paper 19/2014, 15 <https://papers.ssrn.com/sol3/papers.cfm? abstract_id=2520381> accessed 7 March 2020.

6 EU experienced such issues where legal diversity leads to legal unpredictability due to unequal legislation and provisions in EU market. See Helmut Wagner, Economic Analysis of Cross-Border Legal Uncertainty: the Example of the European Union (Fachbereich Wirtschaftswiss, FernUniv. 2004) 3.

7 Oliver Budzinski, 'Lead Jurisdiction Concepts: Prospects and Limits for Rationalizing International Competition Policy Enforcement' (2018) 18 (2) Global Economy Journal;Oliver Budzinski, Towards Rationalizing Multiple Competition Policy Enforcement Procedures: The Role of Lead Jurisdiction Concepts (Universitätsbibliothek Ilmenau 2015) 2. 
precisely the core questions of this study. Hence, this paper begins a discussion by describing the function of harmonization in the ASEAN Economic Community in Part 2. This will be followed by an evaluation of the cross-border competition issues in Part 3 whereby it will not only address the question of whether the harmonization is desirable or not, but it will also examine the problems of the harmonization that are likely to be solved. Part 4 concludes.

Several studies have incredibly analyzed the positive side of the harmonization of competition laws to bridge the gap in the economic community. For example, Jurgita Malinauskaite who explored the harmonization of competition laws in a global context and offered the possible options for dealing with issues among the involved states, ${ }^{8}$ Jusoh, et al., ${ }^{9}$ and Lee and Fukunaga 10 who observed the same thing. This paper highlights the possible legal issues that arise in ASEAN members by examining the experiences of the European Union (EU) or country involved in regional trade agreements, such as the US.
Rather than seeing the whole area of competition law, this paper prefers to focus on two specific areas: the different treatment of market behavior and the legal culture.

\section{DISCUSSION}

\section{ASEAN and Harmonization}

Demands for a more
comprehensive harmonization of
competition law in ASEAN member
states assume that legal diversity has
caused transaction costs and lowers
economic trade and welfare by creating
legal uncertainty. The implementation
of Technical Barriers to Trade (TBT)
could be an example. ${ }^{11}$ Legal harmonization is best suited to the peculiarities of the region and to ASEAN itself rather than legal transplantation of legal unification. ${ }^{12}$

Some studies acknowledged that competition law as the fundamental principle of regional economic integration and harmonization could bring many benefits to the countries which are involved.13 The latest research findings such as Luu, ${ }^{14}$ Thanadsillapakul,15 and Malinaus-

8 Jurgita Malinauskaite, 'Harmonisation in Competition Law in the Context of Globalisation' (2010) 21 European Business Law Review 369.

$9 \quad$ Sufian Jusoh, Yose Rizal Damuri, and Intan Murnira Ramli, 'Regional Regulatory Coherence in the Association of Southeast Asian Nations: The Case of Competition Law and Intellectual Property' in Intal P. and Mari Pangestu (eds), Integrated and Connected Seamless ASEAN Economic Community (ERIA 2019), 127-171.

10 Cassey Lee and Yoshifumi Fukunaga, 'ASEAN Regional Cooperation on Competition Policy' (2014) 35 Journal of Asian Economics 77.

11 Simon Pettman, Standards Harmonisation in ASEAN: Progress, Challenges, and Moving Beyond 2015 (ERIA Discussion Paper Series 2013) 1-2.

12 Legal Transplantation refers to legal systems unilaterally amend their internal rules and adopt rules that are more frequently observed in other legal systems. Legal unification is defined as where countries agree to replace national rules and adopt a unified set of rules chosen at the interstate level. See Joanne Wong, 'On Legal Harmonisation Within ASEAN' (Singapore Law Review, 2013) <http://www.singaporelawreview.com/juris-illuminae-entries/2015/on-legalharmonisation-within-asean> accessed 7 March 2020.

13 Michal S. Gal, 'Regional Competition Law Agreements: An Important Step for Antitrust Enforcement' 201060 (2) The University of Toronto Law Journal 239.

14 Huong Ly Luu, 'Regional Harmonization of Competition Law and Policy: An ASEAN Approach' (2012) 2 (2) Asian Journal of International Law 291.

15 Thanadsillapakul, 'The Harmonization of ASEAN Laws and Policy and Economic Integration Perspective' (n 3) 480. 
kaite, ${ }^{16}$ confirmed that competition law harmonization is essential for the existence of an economic community. ${ }^{17}$ Regional competition law may reduce some significant obstacles to competition law enforcement in developing jurisdictions. ${ }^{18}$ In a common market, competition law has the potential to further the goal of the integrated market.19 Integrating competition policy is valuable as a regional agreement has a wider opportunity to assist the regions in achieving deeper economic integration than the international system could achieve.

A significant benefit offered by regional competition policy is that it eliminates barriers to trade and it makes sure the member countries to enforce their domestic competition laws to ensure the access of firms. ${ }^{20}$ To put it in other words, common standardized rules of competition policy reduce entry barriers to the economic community.

ASEAN adopted the EU style harmonization and the positive expectations have been raised.21 EU has succeeded in achieving harmonization of competition law through the supranational authority. 22 Meanwhile, ASEAN members are still struggling with their efforts to stabilize their new-born competition laws. Some gaps exist among the member states in their levels of enforcement. Diversity in the national levels of enforcement may not only harm the national market but it also may impede the free flow of trade across the ASEAN. Therefore, competition law authorities must establish the proper role of competition policy.

\section{Competition Law Cross-Border Issues}

Enforcing competition policy in economic integration has resulted in some convergences of practice across competition law jurisdictions. These convergences include bridging gaps between developing and developed countries. ${ }^{23}$ The convergence of practice from competition policy harmonization occurred across these areas: cartels, mergers, and vertical restraints.

16 Malinauskaite, 'Harmonisation in Competition Law in the Context of Globalisation' (n 8) 376.

17 OECD, 'Challenges/Obstacles Faced By Competition Authorities In Achieving Greater Economic Development through the Promotion of Competition' (OECD, 2004) <http://www.oecd. org/daf/competition/prosecutionandlawenforcement/25500484.pdf> accessed 13 December 2019.

18 Gal, 'Regional Competition Law Agreements: An Important Step For Antitrust Enforcement' (n 13). Also, see Phanomkwan Devahastin Na Ayudhaya, 'ASEAN Harmonization of International Competition Law: What Is the Most Efficient Option' (2013) 2 (3) International Journal of Business, Economics and Law 1.

19 Lee and Fukunaga, 'ASEAN Regional Cooperation on Competition Policy' (n 10).

20 Gal, 'Regional Competition Law Agreements: An Important Step For Antitrust Enforcement' (n 18).

21 Barbora Valockova, 'EU Competition Law: A Roadmap for ASEAN?' EU Centre Working Paper 25/2015, 2 <https://hdl.handle.net/10356/81660> accessed 11 March 2020.

22 Lee McGowan, 'Theorising European Integration: Revisiting Neo-Functionalism and Testing its Suitability for Explaining the Development of EC Competition Policy?' European Integration Online Papers 4-5 <http://eiop.or.at/eiop/ index.php/eiop/article/view/2007_003a/50> accessed 7 March 2020.

23 Rafaelita M Aldaba, Emerging Issues in Promoting Competition Policy in the APEC and ASEAN Countries ( PIDS Discussion Paper Series 2008) 14. 


\section{Treatment of Market Behaviour}

\section{Export Cartel Agreements}

A potential barrier that ASEAN needs to consider is the differences in the treatment of market behavior. Such a barrier appears in several anticompetitive conduct provisions such as export cartels, vertical restraint, and merger policy. The different treatments of anti-competitive conduct may affect trade relations between countries. Export cartels are deemed as forms of anti-competitive conduct since those arrangements create monopolies in the relevant market. ${ }^{24}$

Those forms of conduct are commonly regarded as acceptable and permitted, while the domestic cartels are forbidden. It is understood that domestic arrangements may harm local consumers, while export cartels can be beneficial. ${ }^{25}$ The commonly given justification is that export cartels will help firms to cope with international trade barriers, reduce the extra costs of exports, and refuse the power of international buying cartels. ${ }^{26}$

Some countries exempt export cartels from their national competition policies as these practices encourage the exercise of market power by their domestic exporting firms, ${ }^{27}$ and they viewed export cartels as an instrument of strategic trade policy. Furthermore, a national government exempting export cartels from the policy in its territory aims to gain supra-normal profits in international markets. ${ }^{28}$

A rationale for export cartels to be exempted from domestic competition law is because it may facilitate cooperative penetration of foreign markets. This will transfer welfare from foreign consumers to domestic firms and result in a balance of trade. Scherer highlights a range of possible cartel situations. ${ }^{29}$ Domestic producers may collaborate with foreign producers in international cartels. Sometimes, these cartels are engaged in market sharing, in which the cartels affect international trade relations as well as facilitating monopoly pricing by engaging in output restrictions ${ }^{30}$.

Virtually, the majority of countries exempt export cartels from their competition policy because export cartels contribute to the national economy positively, as they extract surplus from foreign consumers and transfer it into the profits of homebased companies. ${ }^{31}$ For instance, Taiwan and Japan allow import cartels although the enforcement is restricted. Both countries, as well as South Korea, exempted cartels from their laws.

The Australian Competition and Consumer Commission (ACCC) can authorize an exemption if it is found

\footnotetext{
$24 \quad$ Jurgita Bruneckienė and others, The Impact of Cartels on National Economy and Competitiveness (A Lithuanian Case Study, Springer 2015) 1-47.

25 Michael Ristaniemi, 'Export Cartels and the Case for Global Welfare' Global Antitrust Review <https://ssrn.com/abstract=3166228> accessed 11 March 2020. Also see Christian Schultz, 'Export Cartels and Domestic Markets' (2002) 2 Journal of Industry, Competition and Trade 233. John Sanghyun Lee, Strategies to Achieve a Binding International Agreement on Regulating Cartels (Springer 2016) 253-323.

27 Frederic Desmarais, 'Export Cartels in the Americas and the OAS: Is the Harmonization of National Competition Laws the Solution?' (2009) 33 (1) Manitoba Law Journal 41, 48.

28 Ibid.

29 Frederic M Scherer, Competition Policies For an Integrated World Economy (Brookings Institution Press 1994) 43.

Ibid.

31 Arijit Mukherjee and Uday Bhanu Sinha, 'Export Cartel and Consumer Welfare' (2019) 27 (1) Review of International Economics 91.
} 
that there is a potential benefit that outweighs the potential harm. The annual authorizations for export cartels have declined from a peak of 69 in 1975 to just 4 in 2002. As of 1997, the ACCC reported that it had received 400 export agreement notifications. ${ }^{32}$

$$
\text { The competition policy }
$$

arrangement between Japan and the US faced difficulty when the two countries had different views on export cartels. ${ }^{33}$ The law in Japan authorized legal officers to enforce cartel agreements, while cartel agreements were legalized under the WebbPomrene Export Trade Act of 1918 in the US. However, the US courts did not enforce these agreements, resulting in the cartels were obliged to provide the enforcement mechanism themselves. ${ }^{34}$

In other cases, countries engaged in economic integration or cooperation may exclude export cartels from their competition law. In 2004, a study by Levenstein and Suslow surveyed 56 countries, of which 17 offered exporters an exemption from national competition laws; 35 the rest provided no exemption from regulation for export cartels, but rather exempted them implicitly. Levenstein and Suslow argued that countries with an implicit exemption of export cartels stated that their national laws were silent on restrictive activities that affect foreign markets. ${ }^{36}$ Further, Levenstein and Suslow argued that the structure of national competition laws only restricts activity that harms domestic competition. It leaves a vacuum in which export cartels can operate without any obvious institution to restrict their anti-competitive activities. To avoid this, it is necessary to have international cooperation on export cartel agreements. ${ }^{37}$

\section{Vertical Restraint Assessments}

Vertical restraints refer to a broad range of arrangements between independent firms linked to each other in a buyer-seller relationship. ${ }^{38}$ These arrangements are seen as extremely anti-competitive conduct, intended to build entry barriers against competing products and to gain profit-maximizing margins. ${ }^{39}$ Competition policy on vertical arrangements varies considerably between countries. One of the major difficulties in developing a consistent policy is that economists disagree on the extent of the anticompetitive effects of vertical arrangement. 40

Until the mid-1980s, economists saw vertical restraints were unlikely to

32 Margaret C Levenstein and Valerie Y Suslow, 'The Changing International Status of Export Cartel Exemptions' (2004) 20 (4) American University International Law Review 785, 791.

33 Mitsuo Matsushita, 'Export Control and Export Cartels in Japan' (1979) 20 (1) Harvard International Law Journal 103. Export control laws allowing the formation of export cartels are one of the primary tools available to the Japanese government and Japanese industry for adjusting exports in an attempt to respond to increased scrutiny of imports by foreign countries. Schultz, 'Export Cartels and Domestic Markets' (n 25).

Levenstein and Suslow, 'The Changing International Status of Export Cartel Exemptions' (n 32). Ibid.

Ibid.

UNCTAD, 'Competition Policy and Vertical Restraints: Note/ by the UNCTAD Secretariat.' (UNCTAD, 1999) 1 <https://unctad.org/en/Docs/poitcdclpm8.en.pdf> accessed 19 December 2019.

39 Ibid

40 Ross Jones, 'Economic Integration and Competition Policy: The Agenda for APEC' in Christos Paraskevopoulos, Theodore Georgakopoulos and Leo Micheles (eds), The Asymmetric Global Economy: Growth, Investment and Public Policy (AFP Press 2000). 
restrict ${ }^{41}$ since there was no prime evidence that any restraint improved or reduced economic efficiency. ${ }^{42}$ However, there is now considerable debate among economists as to the anti-competitive impact of vertical arrangements. ${ }^{43}$ The literature lacks consistency, with some economists concluding that vertical restrictions have the potential for both procompetitive and anti-competitive effects. ${ }^{44}$ In some cases, particularly in manufacturing industries, vertical foreclosure is beneficial. ${ }^{45}$

Vertical restraints can help intrabrand coordination in several ways. ${ }^{46}$ For example, by giving the manufacturer direct control over distributors' actions or giving the manufacturer the right to specify retail services or prices. These restrictions can also be used to restructure incentives. For example, a two-part tariff, combining a fixed fee and a price equal to marginal cost, leads a distributor to gain aggregate profits. These restraints may be helpful when there are spillover effects among distributors. Granting exclusive territories can help solve the problem of free-riding in retail services. ${ }^{47}$
Several models have been
constructed to explain how manufacturers benefit from vertical restraints. ${ }^{48}$ The first explanation is that these restraints may facilitate cartel behavior among either manufacturers or distributors. Where this role can be demonstrated, there is broad agreement that vertical restraints promote anti-competitive results and should be prohibited. ${ }^{49}$

Conversely, vertical restraints can also affect inter-brand competition. 50 These practices can reduce competition among existing suppliers by sustaining collusive behavior and by maintaining downstream cartels. In the long run, these restraints can also reduce market competition to block competitors or build entry barriers. Further, manufacturers were able to impose restrictive contracts, despite increasing competition. 51

The first reason is that most distributors were connected to a specific manufacturer by considerable investment in brand-specific equipment and by their customers' loyalty to the manufacturer's welding equipment. These linkage networks

\footnotetext{
41 Ibid.

42 William S Comanor and Patrick Rey, 'Competition Policy Towards Vertical Restraints in Europe and The United States' (1997) 24 Empirica 37, 38.

43 Richard A Posner, 'Vertical Restraints and Antitrust Policy' (2005) 75 (1) The University of Chicago Law Review 229.

44 Dennis W Carlton and Jeffrey M Perloff, Modern Industrial Organization (Pearson Higher Ed 2015) 522-523.

45 William H Rooney, Timothy G Fleming and Sruti Swaminathan, 'Amex in Context: Tracing the Application of the Rule of Reason to Vertical Restraints' (2019) Columbia Business Law Review <https:/ / heinonline.org/HOL/LandingPage?handle=hein.journals / colb2019\&div=4\&id=\&page> accessed December 20, 2019.

46 Comanor and Rey, 'Competition Policy Towards Vertical Restraints in Europe and the United States'(n 42) 47.

Ibid, 37-38.

Ibid.

Ibid.

Ibid.

Ibid.

Paolo Buccirossi, 'Vertical Restraints on E-commerce and Selective Distribution' (2015) 11 (3) Journal of Competition Law \& Economics 747, 747-773. Also see Gerald Brock, 'Industrial Cases' (1989) 19 Journal of Reprints for Antitrust Law and Economics 385, 386-387.
} 
created high costs to distributors of switching gas suppliers entirely. The result is the distributors cannot refuse the restrictive agreement if the alternative would be a significant loss of customers and compensated only by a small cost reduction for a few of the gasses they sell.52 Second, the distributors were moderate in seeing the elevated rivalry at the manufacturing level. At the previous low level of price competition in gasses, the prohibitive contracts would have merely formalized a linkage that business realities already generally directed. 53

To assess vertical restraints, whether they harm competition, some countries use a different approach. There is diversity in the application of the approach based on whether or not it is assumed that vertical restraints have an economic impact. ${ }^{54}$ In particular circumstances, vertical restraints have a positive effect on firms, where vertical agreements lead to increased sales and cut distribution costs. Hence, it will give rise to the most efficient result. However, vertical restraints also have an adverse economic impact. Firms may not always gain efficiency from vertical restraints. They may lead to a reduction in consumer welfare overall. 55
In 1999, UNCTAD released a report regarding competition policy and vertical restraints. It showed that there is a difference in how vertical restraints a reassessed that may bring about a different result.56 This is illustrated in the cases of the EU and APEC in vertical restraints of assessment.

Before 1999, Article 81(1) of the EC Treaty provided the method to evaluate vertical restraints which referred to Block Exemption Regulations. The Regulations were divided into three parts: black, white, and grey. Each of them excluded similar agreements whose procompetitive benefits are considered to outweigh their anti-competitive effects. ${ }^{57}$ The blacklist provision contained prohibitions against vertical agreement unless vetted through an onerous individual exemption procedure; the prohibitions on the white list were exempted under a block exemption, and the procedures in the grey list contained the block exempted agreements. ${ }^{58}$

Vertical restrictions were excluded from the Block Exemption Regulations. In that case, all four criteria of Article 81(3) have to examine: (1) the positive efficiency effects must outweigh the anticompetitive ones; (2) customers should

52 Ronald N Lafferty, Robert H Lande and John B Kirkwood (eds), Impact Evaluations of Federal Trade Commission Vertical Restraints Cases (Federal Trade Commission 1984) 55.

53 Ibid.

54 Alison Jones and Brenda Sufrin, EU Competition Law: Text, Cases and Materials (Oxford University Press 2014) 777-781.

55 William S Comanor, 'Vertical Price-Fixing, Vertical Market Restrictions, and The New Antitrust Policy' 98 (5) Harvard Law Review 983, 985-987.

56 UNCTAD, 'The Use of Economic Analysis in Competition Cases: Study / by the UNCTAD Secretariat' (UNCTAD Secretariat, 2009) 12 <https://digitallibrary.un.org/record/653822> accessed 20 December 2019.

57 Wolfgang Kerber and Simonetta Vezzoso, 'EU Competition Policy, Vertical Restraints, and Innovation an Analysis from an Evolutionary Perspective' (10th International Society Conference Milan/Italy, 9-12 June 2004).

58 UNCTAD, 'The Use of Economic Analysis in Competition Cases: Study/by the UNCTAD Secretariat' (n 56). 
have a fair share of the efficiency gains; (3) the vertical restrictions must be indispensable for the attainment of these efficiencies; and (4) competition must not be lessened; firms are not allowed to become dominant as a consequence of the vertical agreement. This shows that competition analysis of vertical restraints under Article 81 is focused on the efficiencies and the ascertainment of possible indicators of market power, such as the market position of the supplier and competitors, and the presence of entry barriers. ${ }^{59}$

In the US, vertical restraints policies have been sharply varied for more than 30 years. Most of the US policies on vertical restraints are set by judicial decisions, but courts can only rule on cases brought before them. ${ }^{60}$ Exclusive dealing and tie-ins are subject to a competition test under US law such that they are illegal if the result is to lessen competition. There are no specific anti-competitive tests concerning other vertical behaviors, such as third line forcing or territorial restrictions. ${ }^{61}$ It was only in 1967 that the Supreme Court ruled that vertical non-prices, as well as price restraints, were confirmed per se illegal. Subsequently, standards became far more lenient; vertical non-price restraints were to be evaluated by using the rule of reason approach. ${ }^{62}$

\section{Cross-Border Merger Assessment: Market Power v Dominance}

Merger and Acquisition M\&As have various consequences for performance. Cross-border mergers often require the approval of both the acquiring and target firm's shareholders, and the acquiring company assumes the target's assets and liabilities. While in the crossborder acquisition, the control of assets and operations is transferred from a local to a foreign company, with the former becoming an affiliate of the latter.

The purpose of M\&A control is to enable competition authorities to regulate changes in market structure by making decisions as to whether two or more firms may merge, combine, or consolidate their companies into one. ${ }^{63}$ UNCTAD reported that cross-border mergers may result in anti-competitive conduct. It is important to eliminate the anticompetitive effects of crossborder mergers; the adverse effects of cross-border mergers have a considerable impact on economies by changing the structure of the relevant market, thereby increasing exposure to anti-competitive practices. ${ }^{64}$

In this regard, the term crossborder merger refers to mergers that involve firms established in more than one jurisdiction or that affect markets in more than one jurisdiction. Thus, cross-border mergers may directly involve local businesses or may involve

\footnotetext{
$59 \quad$ Kerber and Vezzoso, 'EU Competition Policy, Vertical Restraints, and Innovation An Analysis from an Evolutionary Perspective'(n 57) 4-5.

60 Comanor and Rey, 'Competition Policy Towards Vertical Restraints in Europe and The United States'(n 42).

Ibid.

Ibid.

Jones and Sufrin, EU Competition Law: Text, Cases and Materials (n 54) 1129. UNCTAD, 'Cross-border Anticompetitive Practices: The Challenges for Developing Countries and Economies in Transition' (UNCTAD, 2012) 3 <https://digitallibrary.un.org/record/ 726411> accessed 20 December 2019.
} 
foreign transnational companies, but in the end, it changed to the market of a third country. ${ }^{65}$

The most significant existing merger regimes are the US and EU, since the US merger regime has had an impact on the EU industry, and vice versa. From the early 1940s until the late 1970 s, US anti-competitive rules via antitrust agencies, along with private parties in private litigation, aggressively enforced US antitrust law against firms outside the US jurisdiction and those whose business activities were intended for the US market. ${ }^{66}$ The enormous gap in control between the US and EU regimes brings a high impact on other jurisdictions. Bergman et al. argued that both merger controls may also affect the rest of the world.67 Although global companies need to be concerned about competition rules everywhere, their biggest problems lie with the US and the EU. 68

There are significant differences in the practical analysis of mergers in both jurisdictions. ${ }^{69}$ The US's style of unilateral effects analysis is not carried out in the EU jurisdiction. Indeed, the overall focus of the investigation of the merger analysis is strictly different. 70 Niels and Kate gave more specific points of view on significant differences that exist in the legal and economic standards between different competition law jurisdictions, particularly the US and the EU. Having been brought to light, these differences have generated a great deal of controversy and debate in recent years, most notably in high-profile cases such as Boeing/McDonnell Douglas (1997) and GE/Honeywell (2001). ${ }^{71}$ Coppi and Walker clarified the peculiarity of both regimes, finding that the US merger control emphasizes unilateral effect, while the EU analyses the effects of the M\&S based on the collective dominance of firms. ${ }^{72}$

In assessing whether transborder mergers have adverse effects on competition and consumer welfare, 73 market power and market dominance remain essential elements in merger analysis. ${ }^{74}$ However, there was debate among experts regarding the use of substantive tests versus market

\footnotetext{
65 Ibid., 13.

66 John J Parisi, 'Cooperation Among Competition Authorities in Merger Regulation' (2010) 43 Cornell International Law Journal 55, 57.

67 Mats A Bergman and others, 'Merger Control in the European Union and the United States: Just the Facts' (2011) 7 (1) European Competition Journal 89. David S Evans, 'The New Trustbusters: Brussels and Washington May Part Ways' (2002) 81 Foreign Affairs 14, 15.

69 Lorenzo Coppi and Mike Walker, 'Substantial Convergence or Parallel Paths-Similarities and Differences in the Economic Analysis of Horizontal Mergers in the US and EU Competition Law' (2004) 49 (1-2) Antitrust Bulletin 101, 103.

70 Ibid.

71 Gunnar Niels and Adriaan Ten Kate, 'Introduction: Antitrust in the US and the EU-Converging or Diverging Paths' (2004) 49 (1-2) Antitrust Bulletin 1, 2.

72 Coppi and Walker, 'Substantial Convergence or Parallel Paths-Similarities and Differences in the Economic Analysis of Horizontal Mergers in the US and EU Competition Law' (n 69) 125.

73 Generally, economists agreed that mergers are usually pro-competitive such as enhance consumer welfare because they allow the methods of production to be reorganized and inefficiencies to be removed, thereby creating more efficient firms. Consumers benefit if prices are reduced as costs go down. However, not all mergers are benign, because the structural changes may significantly enhance the market power of the firms in the affected market. Bergman and others, 'Merger control in the European Union and the United States: Just the Facts' (n 67). Coppi and Walker, 'Substantial Convergence or Parallel Paths-Similarities and Differences in the Economic Analysis of Horizontal Mergers in the US and EU Competition Law' (n 69).
} 
dominance tests. ${ }^{75}$ The substantive analysis focuses on the effects of market power whether implicit or explicit. In this regard, the market definition is less significant for the dominance test in the US merger control regime. ${ }^{76}$ This approach has been used by several countries worldwide, including the US, ${ }^{77}$ Canada, New Zealand, France, Ireland, South Africa, and the United Kingdom. ${ }^{78}$

The US test for a merger is based on whether it is likely to result in a significant lessening of competition as subjected to Section 7 of the Clayton Act. Generally, the US agencies focused on the assessment of market concentration after a merger was established by using the HHI index.79 When using the index, FTC considers both after the merger level of the HHI and the increase of market concentration resulting from the merger.
The increase in the HHI can be indicated by the amount of market share product of the merging firms, particularly when it shows double after the merger. ${ }^{80}$ The Agencies classify markets into three types: 81

a) Unconcentrated markets: HHI below 1500 .

b) Moderately concentrated markets: HHI between 1500 and 2500.

c) Highly concentrated markets: HHI above 2500 .

The index is necessary as it reflects the concentration of firms' output. ${ }^{82}$ The HHI index is essential because it has characteristics of being correlated with the level of industrywide profits based on the Cournot model of competition. ${ }^{83}$ In the Cournot model of competition, there is a strong relationship between market power and level of industry profits to overall

75 Julie N Clarke, 'Multi-Jurisdictional Merger Review Procedures-A Better Way' (2006) 14 (2) Trade Practices Law Journal 90.

76 Coppi and Walker, 'Substantial Convergence or Parallel Paths-Similarities and Differences in the Economic Analysis of Horizontal Mergers in the US and EU Competition Law' (n 69), 104-105. In general, the more narrow the market is defined the more likely firms will be found to have market power. See Patrick Massey, 'Market Definition and Market Power in Competition Analysis: Some Practical Issues' (2000) 31 (4) The Economic and Social Review 309, 310. Furthermore, in the US there is a general trend toward reduced reliance on market definition since the utilization of unilateral effect theories.

77 Bergman and others, 'Merger control in the European Union and the United States: Just the Facts' (n 67).

78 Clarke, 'Multi-Jurisdictional Merger Review Procedures-A Better Way' (n 75).

79 Suppose there are ten firms in a market in which each has a $10 \%$ market share, the HHI would be $(10) 2+(10) 2+\ldots+(10) 2=1,000$. By contrast, a market with one firm that has a $50 \%$ share and five firms each with a $10 \%$ share would have an HHI of $(50) 2+(10) 2+(10) 2+\ldots .(10) 2=3,000$. The HHI ranges from 10,000 (in the case of a pure monopoly) to a number approaching zero (in the case of an atomistic market). SeeFred H Hays and Sidne Gail Ward, 'Understanding Market Concentration: Internet-Based Applications from the Banking Industry' Journal of Instructional Pedagogies 1, 2 <https://eric.ed.gov/?id=EJ1096952> accessed 20 December 2019.

80 For example, the merger of firms with shares of five percent and ten percent of the market would increase the HHI by $100(5 \times 10 \times 2=100)$. See the U.S. Horizontal Merger Guidelines 2010 at U.S. Department of Justice and the Federal Trade Commission, 'Horizontal Merger Guidelines 2010' (USDOJ, 2010) 19 <http://www.justice.gov/atr/public/guidelines/hmg-2010.html> accessed 8 June 2019.

81 Ibid., Section 5.3, 20.

82 Stephen A Rhoades, 'Market Share Inequality, the HHI, and Other Measures of the FirmComposition of a Market' (1995) 10 Review of Industrial Organization 657.

83 Jacob A Bikker and Michiel van Leuvensteijn, A New Measure of Competition in the Financial Industry: The Performance-conduct-structure Indicator (Routledge 2014) 84. 
concentration as measured by the HHI. 84

Conversely, the second method other than the HHI prohibits mergers when they create or enhance a position of dominance in the relevant market. The EU used this method before the latest merger regulation of $2004.85 \mathrm{In}$ 1990, the EU adopted the EU Merger Regulation. This regulation prohibited mergers that strengthen a dominant position as a result of which effective competition would be significantly lessened. ${ }^{86}$ The Merger Regulation was aimed at permitting effective control of all concentrations from their effect on the structure of competition in the Community and to be the only instrument applicable to such concentrations. ${ }^{87}$

In the European experience, since the establishment of the European Economic Community, the wave of mergers has increased to a significant level. Merger policy was not explicitly dealt with in the Treaty of Rome in 1957. Rather, it has traditionally been guided by a comprehensive interpretation of Articles 85 and 86 of the Treaty. More recently, however, a new regulation was approved as an attempt at creating the basis for an EU-wide merger policy. ${ }^{88}$
According to Jacquemin, the existing data reflects that the sum of M\&As involving at least one of the top $1,000 \mathrm{EU}$ firms has been steadily developing with positive progress, 89 increasing from 185 in 1984-1985 to 492 in 1988-1989. Among these top 1,000 firms, companies with sales of over 1 billion (based on European currency) were involved in $75 \%$ of mergers in 1988-1989, compared to $50 \%$ in 1984-1985.90 The market shares of the merging firms were too large and threatened consumer welfare. The logical reason is the more power the merging firms hold before the merger, the larger the cost reduction has to be for the after-merger price to fall. 91

In the GE-Honeywell merger case, the center of the conflict between two competition policy systems was that each used a different theory. The US expressed disagreement with the EU's decision, pointing out the different methods used to evaluate the impact of the merger, yielding different results. ${ }^{92}$ The EU applied the range effect theory and the entrenchment doctrine to assess the merger of GE-Honeywell. Under both theories, the merger could be condemned if it strengthened an already dominant firm through greater

Toby Roberts, 'When Bigger is Better: A Critique of the Herfindahl-Hirschman Index's use to Evaluate Mergers in Network Industries' (2014) 34 (2) Pace Law Review 1.

Lars-Hendrik Röller and Miguel De La Mano, 'The Impact of the New Substantive Test in European Merger Control' (2006) 2 (1) European Competition Journal 9.

Ibid., 10.

Council Regulation (EC) 139/2004 the Control of Concentrations Between Undertakings (EC Merger Regulation) (2004) OJ L24/29.1.2004 P 1-22.

Council Regulation (EC) 4064/1989 on the control of Concentrations Between Undertakings (EC Merger Regulation) [1989] OJ L 257/90 P 13 has been substantially amended.

Alexis Jacquemin, 'Horizontal Concentration and European Merger Policy' (1990) 34 92-3) European Economic Review 539. Pedro P. Barros, 'Merger Policy in Open Economies' (1994) 38

(5) European Economic Review 1041, 1047-1048.

Barros, 'Merger Policy in Open Economies' (n 89).

Jacquemin, 'Horizontal Concentration and European Merger Policy' (n 89) 544.

Eleanor Morgan and Steven McGuire, 'Transatlantic Divergence: GE-Honeywell and the EU's Merger Policy' (2004) 11 (1) Journal of European Public Policy 39-56. Also, see David J Gerber, 'The European Commission's GE/Honeywell Decision: US Responses and Their Implications' (2003) Zeitschrift für Wettbewerbsrecht [Journal of Competition Law] 87. 
efficiencies or gave acquired firm access to a broader line of products or greater financial resources, thus making business more difficult for small firms. For that reason, the US eliminated the use of these theories for examining non-horizontal mergers. Also, these theories are no longer used because empirical evidence could not show that this would harm the competition. ${ }^{93}$

In the EU itself, the enforcement of the Old Regulation raised important question due to it resulting in different interpretations. Therefore, a lot of changes were made in its performance. One alternative interpretation articulated that market concentration is forbidden whenever it leads to the creation or strengthening of a dominant position and if the effect of such change in the market structure amounts to a significant barrier to competition. ${ }^{94}$

In this case, dominance is quite necessary but not sufficient to prove the negative impact of the merger in the relevant market. The second alternative interpretation is that mergers that create or strengthen a dominant position will automatically harm competition. ${ }^{95}$ The opponents of this analysis argue that dominance is both necessary and enough and constitutes a single condition. 96
To overcome these multiple interpretations of the substantive test, the EU adopted the 2004 New Merger Regulation and reformulated the substantive tester of the SIEC test as follows:
A concentration that would significantly impede effective competition, in particular by the creation or strengthening of a dominant position, in the common market or a substantial part of it shall be declared incompatible with the common market. 97

The 2004 changed merger regulations had a similar methodology to those in the US, introducing a multifirm unilateral effect, along with an efficiency defense and the use of a hypothetical monopoly test to define the market. 98 According to the 2004 Regulation, concentration is to be welcomed if it is not damaging to competition, but rather increases the competitiveness of the entire European industry and raises living standards. 99 It should maintain and develop effective competition. The resulting expansion of technical and economic progress should benefit the consumer's welfare. 100

However, the dominance test standard under the 2004 Regulation is differently worded from the US merger

\footnotetext{
93 Ricky D Rivers, 'General Electric/Honeywell Merger: European Commission Antitrust Decision Strikes a Sour Note' (2002) 9 ILSA Journal of International \& Comparative Law 525, 528.

94 Röller and De La Mano, 'The Impact of the New Substantive Test in European Merger Control' (n 85) 9.

Ibid.

Ibid., 11.

Council Regulation (EC) 139/2004 on the Control of Concentrations between Undertakings (EC Merger Regulation)' [2004] OJ L24/29.1.2004 P 1-22.

98 Bergman and others, 'Merger control in the European Union and the United States: Just the Facts' (n 67).

99 Council Regulation (EC) 139/2004 on the Control of Concentrations between Undertakings (EC Merger Regulation [2004] OJ L24/29.1.2004 P 1-22.

100 Adél Németh and Hans-Martin Niemeier, 'Airline Mergers in Europe-An Overview on the Market Definition of the EU Commission' (2012) 22 Journal of Air Transport Management 45, 48.
} 
regimes. ${ }^{101}$ In contrast to the US definition of dominance, the EU defines dominance as a position of economic strength enjoyed by a firm that enables it to prevent its competitors from entering into the market so that effective competition cannot be maintained on the relevant market. ${ }^{102}$ By affording its power, a firm also abuses its power to control the price. Dominance in this perspective remains the core principle of Article 2 of the Merger Regulation. The new SIEC test does not require the presence of dominance as the prerequisite to defining market power, based on the reason that if dominance is properly accepted as significant market power, then there is no reason for market leadership to be necessary for a dominant position. ${ }^{103}$

In dealing with anti-competitive conduct, some cooperation agreements were established, including the international measures provided for in the Set of Multilaterally Agreed Equitable Principles and Rules for the Control of Restrictive Business Practices negotiated under the auspices of UNCTAD. Another international measure is the OECD
Recommendation on Merger Review 2005, which stresses the importance of cooperation and coordination in reviewing transnational mergers. ${ }^{104}$

\section{Legal Culture}

Differences in national legal cultures may affect competition law in regional cooperation. ${ }^{105}$ Differences in legal culture in member states in a regional trade agreement also enhance the obstacles to the enforcement of competition law. ${ }^{106}$ Kim Them Do107 mentioned in a study that different legal cultures may create crucial obstacles to economic integration. The culture and the social conditions of a country affect its enforcement of the law; Cotterel observed this as the relationship of culture to the application of the law. ${ }^{108}$ Similarly, Lawrence Friedman argued that culture is another significant element that defines a legal system in one country, after legal substance and legal structure such as procedural law and court decisions. ${ }^{109} \mathrm{He}$ further added that the culture relates to the values and attitudes that link the system together and that determine the place of the legal system in the culture of the

101 Nicholas Levy, 'EU Merger Control: From Birth to Adolescence' (2003) 26 (2) World Competition 195, 200.

102 Jones and Sufrin, EU Competition Law: Text, Cases and Materials (n 54) 284.

103 Röller and De La Mano, 'The Impact of the New Substantive Test in European Merger Control' (n 85) 15.

104 OECD, 'The Standard For Merger Review' (OECD, 2009) 8 <http://search.oecd.org/ daf/competition/mergers/45247537.pdf> accessed 13 December 2019. Also, see Roman Inderst and Nicola Mazzarotto, 'Can the SIEC Test Be Used to Assess Effects from Buyer Power?' (2017) 8 (3) Journal of European Competition Law \& Practice 185.

$105 \mathrm{Ki}$ Jong Lee, 'Culture and Competition: National and Regional Levels' (2008) 21 (1) Loyola Consumer Law Review 33.

106 Aldaba, Emerging Issues in Promoting Competition Policy in the APEC and ASEAN Countries (n 23) $1-10$.

107 Kim Them Do, 'Competition Law and Policy and Economic Development in Developing Countries' (2011) 8 Manchester Journal of International Economic Law 18, 19. Also see Kim Them Do, 'The Perspectives of International Cooperation in Competition Law and Policy' (2009) 3 Zeitschriftt fir Wettbewerbsrecht (ZWeR) Journal of Competition Law 298, 303.

108 Roger Cotterrell, 'Law in Culture' (2004) 17 (1) Ratio Juris 1.

109 Lawrence M. Friedman, 'Legal Culture and Social Development' (1969) 4 (1) Law \& Society Review 29, 34. 
society as a whole'.110 Without understanding the culture of a country, it would be difficult to design a law regime for them to adopt. Ultimately, implementing transnational competition law would not be simple because cultural barriers or issues should be understood in the context of the member states themselves. ${ }^{111}$

In Japan, for instance, there is a cultural barrier to accepting new competition owing to the great success of the prevailing competition culture, which has influenced economic stability. ${ }^{112}$ Cultural differences have played a role even within the EU economic community, where the strength of the competition culture of member states varies. For example, the UK and Ireland are developing a firmer competition culture, with strong criminal enforcement against cartels, whereas most other members seem to waver in this regard. ${ }^{113}$

In 2002, the OECD reported penalizing hard-core cartels in several countries, and that the process of doing so was influenced by the culture of each country.114 Of these countries-Australia, Canada, France, Germany, Ireland, Japan, Korea, Mexico, New Zealand, Norway, Slovak, Spain, and the US-only nine provided for criminal sanctions, such as imprisonment, for those involved in anti-competitive conduct. The nine countries were Canada, Germany, Ireland, Japan, Korea, Mexico, Norway, the Slovak Republic, and the US. ${ }^{115}$ Canada and the US are also known for meting out goal punishment to executives who become involved with cartels. UK and Ireland also imposed criminal sanctions on executives for cartel activity. ${ }^{116}$

There is a reasonable explanation as to why legal implementation could vary according to culture.117 First, nations with individualistic values have more severe anti-cartel policies than those with collective cultures; second, nations with a stronger tendency to avoid uncertainty are inclined to have a relatively lenient anti-cartel instrument. Third, countries that show the mixed cultural values, tend to have a more rigorous anti-cartel policy; and fourth, cluster countries such as Canada and the United Kingdom, tend to have a less rigorous anti-cartel policy. ${ }^{118}$ Cartels are deemed a direct restraint against competition law; Lee opines that a lenient anti-cartel policy indicates a fairly weak competition culture, while a rigorous anti-cartel policy manifests in a stronger competition culture.

There has also been debate regarding the connection between culture and harmonization of law in

\footnotetext{
110 Ibid.

111 OECD, 'Challenges/Obstacles Faced by Competition Authorities in Achieving Greater Economic Development through the Promotion of Competition' (n 17).

112 Lee, 'Culture and Competition: National and Regional Levels' (n 105).

113 Ibid.

114 OECD, 'Fighting Hard Core Cartels: Harm, Effective Sanctions and Leniency Programmes' (OECD, 2002) <https://doi.org/10.1787/9789264174993-en> accessed 13 December 2019.

115 Ibid.

116 Paul Gorecki, 'Competition Policy in Ireland: A Good Recession?' (2012) ESRI Working Paper 1/2012 1-26 <http://www.tara.tcd.ie/xmlui/handle/2262/63752> accessed 19 December 2019.

117 Lee, 'Culture and Competition: National and Regional Levels' (n 105)39.

118 Ibid.
} 
the economic communities.119 For example, the EU facing an identity crisis in its process. Article 167 of the TFEU regulates the balance between contributing to member states' cultures while respecting the national identity and moving the common European cultural heritage forward. ${ }^{120}$ Accordingly, a broad interpretation of culture should be allowed in the context of harmonization so that cultural diversity covers, inter alia, legal as well as societal diversity. ${ }^{121}$

However, in the context of ASEAN economic integration, the cultural identities of the member states, including their political and socioeconomic environments, are fragile issues. ${ }^{122}$ For sure, ASEAN will rely on the 'deliberation' and 'consensus' principles to reach agreement on issues such as harmonizing ASEAN members' competition laws into a regional system that respects cultural sensitivities and national sovereignty. ${ }^{123}$ Regardless of the competencies of the economic community member states, the importance of cooperation must be emphasized, since it requires the economic community to take cultural aspects into account in its action under the other provisions of regulations, particularly to respect and promote diversity. This implies that when the economic community sets out its process of harmonizing domestic laws, it must take cultural considerations into account. ${ }^{124}$

\section{CONCLUSION}

There is a reason why some regional economic communities delay or avoid the process of harmonization stem from the perception of different treatment to market behavior. Another obstacle is the problem of legal culture and the effect of the history of a nation on its competition policy and law. The central point regarding this obstacle is that ASEAN member states legal differences often stem from different cultures and social preferences. Specific rules are often suited to local traditions and customs, and even if harmonization enhances foreign trade opportunities among the member states, it may impose quite substantial short-run adaptation costs. Accordingly, the chance to harmonize different competition policies and laws in the ASEAN member states cannot be ultimately seen as an uncontroversial positive effort or one that is free of conflict. The increased integration of trade and national laws also creates fault-lines of cultural dissonance.

\section{REFERENCES}

\section{Books}

Bikker JA and Van Leuvensteijn M, A New Measure of Competition in

119 Ruth Sefton-Green, 'Multiculturalism, Europhilia and Harmonization: Harmony or Disharmony' Utrecht Law Review <www.utrechtlawreview.org> accessed December 15, 2019

120 Ibid.

121 Ibid.

122 Ploykaew Porananond, Competition Law in the ASEAN Countries (Kluwer Law International BV 2018).

123 Wong, 'On Legal Harmonisation Within ASEAN' (n 12). This paper limits its analysis on the difficulties of harmonizing competition laws into the regional system, specifically on the market behavior and legal culture. The sovereignty of the ASEAN member states is beyond the paper discussion.

124 Sefton-Green, 'Multiculturalism, Europhilia and Harmonization: Harmony or Disharmony' (n 119). 
the Financial Industry: The Performance-conduct-structure Indicator (Routledge 2014).

Bruneckiene $\mathrm{J}$ and others, The Impact of Cartels on National Economy and Competitiveness (A Lithuanian Case Study, Springer 2015).

Budzinski O, Towards Rationalizing Multiple Competition Policy Enforcement Procedures: The Role of Lead Jurisdiction Concepts (Universitätsbibliothek Ilmenau 2015).

Carlton DW and Perloff JM, Modern Industrial Organization (Pearson Higher Ed 2015).

Chia SY, The ASEAN Economic Community: Progress, Challenges, and Prospects', A World Trade Organization for the 21st Century (Edward Elgar Publishing 2014).

Jones A and Sufrin B, EU Competition Law: Text, Cases, and Materials (Oxford University Press 2014).

Jones R, 'Economic Integration and Competition Policy: The Agenda for APEC' in Paraskevopoulos C, Georgakopoulos T and Micheles L (eds), The Asymmetric Global Economy: Growth, Investment and Public Policy (AFP Press 2000).

Jusoh S, Damuri YZ, and Ramli IM, 'Regional Regulatory Coherence in the Association of Southeast Asian Nations: The Case of Competition Law and Intellectual Property' in Intal P. and Mari Pangestu (eds), Integrated and Connected Seamless ASEAN Economic Community (ERIA 2019).

Lee JS, Strategies to Achieve a Binding International Agreement on
Regulating Cartels (Springer 2016).

Lafferty RN, Lande RH, and Kirkwood JB (eds), Impact Evaluations of Federal Trade Commission Vertical Restraints Cases (Federal Trade Commission 1984).

Neven D and Seabright P, 'Trade Liberalization and the Coordination of Competition Policy' in William S Comanor, Akira Goto and Leonard Waverman (eds), Competition Policy in the Global Economy: Modalities for Co-operation (Routledge 2005).

Porananond $\mathrm{P}$, Competition Law in the ASEAN Countries (Kluwer Law International BV 2018).

Scherer FM, Competition Policies For an Integrated World Economy (Brookings Institution Press 1994).

Wagner H, Economic Analysis of CrossBorder Legal Uncertainty: the Example of the European Union (Fachbereich Wirtschaftswiss, FernUniv. 2004).

\section{Article Journals}

Barros PP, 'Merger Policy in Open Economies' (1994) 38 European Economic Review.

Bergman MA and others, 'Merger Control in the European Union and the United States: Just the Facts' (2011) 7 (1) European Competition Journal.

Buccirossi P, 'Vertical Restraints on Ecommerce and Selective Distribution' (2015) $11 \quad$ (3) Journal of Competition Law \& Economics. 
Brock G, 'Industrial Cases' (1989) 19 Journal of Reprints for Antitrust Law and Economics.

Budzinski O, 'Lead Jurisdiction Concepts: Prospects and Limits for Rationalizing International Competition Policy Enforcement' (2018) 18 (2) Global Economy Journal.

Clarke JN, 'Multi-Jurisdictional Merger Review Procedures-A Better Way' (2006) 14 (2) Trade Practices Law Journal.

Comanor WS, 'Vertical price-Fixing, Vertical Market Restrictions, and The New Antitrust Policy' 98 (5) Harvard Law Review. and Rey P, 'Competition Policy Towards Vertical Restraints in Europe and The United States' (1997) 24 Empirica.

Coppi L and Walker M, 'Substantial Convergence or Parallel PathsSimilarities and Differences in the Economic Analysis of Horizontal Mergers in the US and EU Competition Law' (2004) 49 (1-2) Antitrust Bulletin.

Cotterrell R, 'Law in Culture' (2004) 17

(1) Ratio Juris.

Desmarais F, 'Export Cartels in the Americas and the OAS: Is the Harmonization of National Competition Laws the Solution?' (2009) 33 (1) Manitoba Law Journal.

Do KT, 'The Perspectives of International Cooperation in Competition Law and Policy' (2009) 3 Zeitschriftt fir Wettbewerbsrecht (ZWeR) Journal of Competition Law.
--------, 'Competition Law and Policy and Economic Development in Developing Countries' (2011) 8 Manchester Journal of International Economic Law.

Evans DS, 'The New Trustbusters: Brussels and Washington May Part Ways' (2002) 81 Foreign Affairs.

Friedman LM, 'Legal Culture and Social Development' (1969) 4 (1) Law \& Society Review.

Gal MS, 'Regional Competition Law Agreements: An Important Step for Antitrust Enforcement' 2010 60 (2) The University of Toronto Law Journal.

Gerber DJ, 'The European Commission's GE/Honeywell Decision: US Responses and Their Implications' (2003) Zeitschrift für Wettbewerbsrecht [Journal of Competition Law].

Hays FH and Ward SG, 'Understanding Market Concentration: InternetBased Applications from the Banking Industry' Journal of Instructional Pedagogies $<$ https:// eric.ed.gov/?id=EJ1096 952> accessed 20 December 2019.

Inderst $\mathrm{R}$ and Mazzarotto $\mathrm{N}$, 'Can the SIEC Test Be Used to Assess Effects from Buyer Power?' (2017) 8 (3) Journal of European Competition Law \& Practice.

Irawan C, 'Legal Harmonization in ASEAN Economic Communities (Looking for the Best Legal Harmonization Model)' (2018) 3 (2) University Of Bengkulu Law Journal.

Jacquemin A, 'Horizontal Concentration and European 
Merger Policy' (1990) 34 (2-3) European Economic Review.

Lee $\mathrm{C}$ and Fukunaga $\mathrm{Y}$, 'ASEAN Regional Cooperation on Competition Policy' (2014) 35 Journal of Asian Economics.

Lee KJ, 'Culture and Competition: National and Regional Levels' (2008) 21 (1) Loyola Consumer Law Review.

Levenstein MC and Suslow VY, 'The Changing International Status of Export Cartel Exemptions' (2004) 20 (4) American University International Law Review.

Levy N, 'EU Merger Control: From Birth to Adolescence' (2003) 26 (2) World Competition.

Luu HL, 'Regional Harmonization of Competition Law and Policy: An ASEAN Approach' (2012) 2 (2) Asian Journal of International Law.

Malinauskaite $\mathrm{J}$, 'Harmonisation in Competition Law in the Context of Globalisation' (2010) 21 European Business Law Review.

Massey P, 'Market Definition and Market Power in Competition Analysis: Some Practical Issues' (2000) 31 (4) The Economic and Social Review.

Matsushita M, 'Export Control and Export Cartels in Japan' (1979) 20 (1) Harvard International Law Journal.

Morgan E and McGuire S, 'Transatlantic Divergence: GEHoneywell and the EU's Merger Policy' (2004) 11 (1) Journal of European Public Policy.

Mukherjee A and Sinha UB, 'Export Cartel and Consumer Welfare'
(2019) $27 \quad$ (1) Review of International Economics.

$\mathrm{Na}$ Ayudhaya PD, 'ASEAN Harmonization of International Competition Law: What Is the Most Efficient Option' (2013) 2 (3) International Journal of Business, Economics, and Law.

Németh $A$ and Niemeier $H$, 'Airline Mergers in Europe-An Overview on the Market Definition of the EU Commission' (2012) 22 Journal of Air Transport Management.

Niels $\mathrm{G}$ and Kate AT, 'Introduction: Antitrust in the US and the EUConverging or Diverging Paths' (2004) 49 (1-2) Antitrust Bulletin.

Parisi JJ, 'Cooperation Among Competition Authorities in Merger Regulation' (2010) 43 Cornell International Law Journal.

Posner RA, 'Vertical Restraints and Antitrust Policy' (2005) 75 (1) The University of Chicago Law Review.

Rhoades SA, 'Market Share Inequality, the HHI, and Other Measures of the Firm-Composition of a Market' (1995) 10 Review of Industrial Organization.

Rivers RD, 'General Electric/Honeywell Merger: European Commission Antitrust Decision Strikes a Sour Note' (2002) 9 ILSA Journal of International \& Comparative Law.

Roberts T, 'When Bigger is Better: A Critique oftheHerfindahlHirschman Index's use to Evaluate Mergers in Network Industries' (2014) 34 (2) Pace Law Review. 
Röller L and De La Mano M, 'The Impact of the New Substantive Test in European Merger Control' (2006) 2 (1) European Competition Journal.

Rooney WH, Fleming TG and Swaminathan S, 'Amex in Context: Tracing the Application of the Rule of Reason to Vertical Restraints' (2019) Columbia Business Law Review <https://heinonline.org/HOL/La ndingPage?handle=hein.journals / colb2019\&div $=4 \&$ id $=$ \&page $>$ accessed 20 December 2019.

Schultz C, 'Export Cartels and Domestic Markets' (2002) 2 Journal of Industry, Competition, and Trade.

Thanadsillapakul L, 'The Harmonization of ASEAN Laws and Policy and Economic Integration' (2004) 3 Uniform Law Review.

\section{Working Papers}

Cauffman C and Philipsen NJ, 'Who Does What in Competition Law: Harmonizing the Rules on Damages for Infringements of the EU Competition Rules?' Maastricht European Private Law Institute Working Paper 19/2014 <https:// papers.ssrn.com/sol3/ papers.cfm?abstract_id $=252038$ $1>$ accessed 7 March 2020.

Paul Gorecki, 'Competition Policy in Ireland: A Good Recession?' (2012) ESRI Working Paper $427 / 2012<$ http://www.tara.tc d.ie/xmlui/handle/2262/63752 > accessed 19 December 2019.

Valockova B, 'EU Competition Law: A Roadmap for ASEAN?' EU Centre Working Paper 25/2015 < https:
/ /hdl.handle.net/10356/81660> accessed 11 March 2020.

\section{Seminar/Conference}

Kerber W and Vezzoso S, 'EU Competition Policy, Vertical Restraints, and Innovation An Analysis from an Evolutionary Perspective' (10th International Society Conference Milan/Italy, 9-12 June 2004).

\section{Website}

McGowan L, 'Theorising European Integration: Revisiting NeoFunctionalism and Testing its Suitability for Explaining the Development of EC Competition Policy?' European Integration Online Papers <http://eiop.or. at/eiop/ index.php/eiop/article/ view/2007_003a/50> accessed 7 March 2020.

OECD, 'Fighting Hard Core Cartels: Harm, Effective Sanctions and Leniency Programmes' (OECD, 2002) <https://doi.org/10.1787/ 9789264174993-en $>$ accessed 13 December 2019.

-, 'Challenges/Obstacles Faced by Competition Authorities in Achieving Greater Economic Development through the Promotion of Competition' (OECD, 2004) < http:/ / www.oecd. org/daf/competition/prosecutio nandlawenforcement/25500484. pdf $>$ accessed 13 December 2019.

-, 'The Standard For Merger Review' (OECD, 2009) 8 <http:// search.oecd.org/daf/competition /mergers / 45247537.pdf> accessed 13 December 2019. 
Ristaniemi M, 'Export Cartels and the Case for Global Welfare' Global Antitrust Review <https://ssrn. com/abstract $=3166228>$ accessed 11 March 2020.

Sefton-Green R, 'Multiculturalism, Europhilia and Harmonization: Harmony or Disharmony' Utrecht Law Review <www.utrecht lawreview.org $>$ accessed 15 December 2019.

The U.S. Horizontal Merger Guidelines 2010 at U.S. Department of Justice and the Federal Trade Commission, 'Horizontal Merger Guidelines 2010' (USDOJ, 2010) <http://www.justice.gov/atr/pu blic/guidelines/hmg-2010.html> accessed 8 June 2019.

UNCTAD, 'Competition Policy and Vertical Restraints: Note / by the UNCTAD Secretariat.' (UNCTAD, 1999) <https://unctad.org/en/ Docs/poitcdclpm8.en.pdf> accessed 19 December 2019.

----------, 'The Use of Economic Analysis in Competition Cases: Study/by the UNCTAD Secretariat' (UNCTAD, 2009) <https:/ / digitallibrary.un.org/re cord/653822> accessed 20 December 2019.

tive Practices: The Challenges for Developing Countries and Economies in Transition' (UNCTAD, 2012) 3 <https://digi tallibrary.un.org/record/726411 > accessed 20 December 2019.

Wong $J$, 'On Legal Harmonisation Within ASEAN' (Singapore Law Review, 2013) <http://www. Singaporelawreview.com/juris-ill uminae-entries/2015/on-legal- harmonisation-within-asean> accessed 7 March 2020.

\section{Regulation}

Council Regulation (EC) 4064/89 on the Control of Concentrations Between Undertakings (EC Merger Regulation) [1989] OJ L257/90 P 13.

Council Regulation (EC) 139/2004 on the Control of Concentrations between Undertakings (EC Merger Regulation)' [2004] OJ L24/29.1.2004 P 1-22.

\section{Others}

Pettman S, Standards Harmonisation in ASEAN: Progress, Challenges, and Moving Beyond 2015 (ERIA Discussion Paper Series 2013).

Aldaba RM, Emerging Issues inPromoting Competition Policy in the APEC and ASEAN Countries (PIDS Discussion Paper Series 2008). 
